\title{
The Global Precariat: Refugees and COVID-19
}

\author{
Srinita Bhattacharjee \\ University of Hyderabad. ORCID: oooo-0oo3-4773-7045. \\ Email: srinitabhattacharjee@gmail.com
}

\begin{abstract}
Are refugees welcomed by nation-states? Receiving a hospitable environment to resow the seeds of survival is a fundamental right of any human individual especially for refugees who have been rendered stateless and rightless. They require magnanimous hospitality in the form of social solidarity but what they acquire are disdainful attacks from neoliberal nation-states. Often their traumatic voyages towards a secured mode of living meet with dejection and despair when nation-states violate their obligations by refusing to grant them asylum. The few, who are accepted, are also compelled to hover around nation-state peripheries with ruthless indifference awaiting them. I shall critically consider Derridean 'hostipitality' as the premise to problematize refugee identity as the locus of precarity ensued by radical alterities.
\end{abstract}

Keywords: refugee, COVID, precarity, hostipitality, neoliberalism

\section{Introduction}

The significant practice associated with the welcoming of guests inside our home is configured through the gesture called 'hospitality'. In Derridean philosophy, however, the term 'hospitality' is infused with major contradictions. The hospitality which simply connotes as a generous reception of guests, visitors, or even strangers and also perhaps sharing the home is not an unconditional act of kindness on the part of the host. Hospitality is accepting the individual without a true comprehension of the individual's identity, which is certainly not practiced in reality. The act of receiving and welcoming the guest inside the home of the host by the host is characterized by certain inherent hostilities. Derrida states, “...from the outset hospitality limits itself at its very beginning, it remains forever on the threshold of itself...it governs the thresholdand hence it forbids in some way even what it seems to allow to cross the threshold to pass across it." (2000,14)

Absolute unconditional hospitality, according to Derrida, would not restrict the guest at the threshold for interrogating the identity of the guest. It would have given the guest unlimited entry to the host's home but since there are a threshold and a door that can be opened only by the host to accept the guest, then hospitality is ingrained with conditions. The sovereignty over the home displayed in the act of welcoming the guest who is standing at the threshold until welcomed to step inside by the host proves that the guest is not unconditionally welcomed by the host. Moreover, even a benevolent host welcomes the guest with the words "... you are welcome in my home, without any implication of making yourself at home..." $(2000,14)$ The guest is welcomed as a temporary visitor and not a resident of the home and even as a visitor the guest

(C) AesthetixMS 2020. This Open Access article is published under a Creative Commons Attribution Non-Commercial 4.o International License (http://creativecommons.org/licenses/by-nc/4.o/), which permits non-commercial re-use, distribution, and reproduction in any medium, provided the original work is properly cited. For citation use the DOI. For commercial re-use, please contact editor@rupkatha.com. 
has to abide, respect, and observe the laws of the home declared and practiced by the host. It could be inferred that the guest who has been provided with a home by the host cannot cultivate mastery over the home, the enjoyment of rights and privileges by the guest is limited to what the host offers and it is the host who also decides the extent of this enjoyment. Hence the notion of hospitality, and unlimited practice of selflessly sharing one's space (home), and everything that it encompasses is a myth, as Derrida asserts that

"it gives, it offers, it holds out, but what it gives, offers, holds out, is the greeting which comprehends and makes or lets come into one's home, folding the foreign Other into the internal law of the host which tends to begin by dictating the laws of its language and its own ... concepts as well" (Derrida, 2000, 7)

In other words, the greeting of the host, the one who receives the guest/Other, is only bestowed on the condition of an affirmation, and therefore maintenance of the host's authority and the law of household.

\section{Hostipitality}

The liberal concept of hospitality is aporetic which simultaneously combines the assertion of a home whose host both welcomes the Other and imposes certain hostile conditions on the Other. Therefore, Derrida proposes and endorses 'hostipitality' (2000) which unlike its absolute form is a social practice that is conditional. The Derridean portmanteau 'hostipitality' --- hospitality conditioned with inherent hostilities--- reveals the complex relationship between enmity and generosity in the acts of hospitality where host and guest are engaged. This philosophical stance reflects upon the laws and policies of immigration that neoliberal nation-states have shaped in addressing the crisis encountered by refugees. In this essay, I invoke the Derridean conceptualization of 'hostipitality' while probing the alterities encountered by the refugee subjectivities in the wake of the pandemic. The casualties of state conflicts and now the COVID, refugees are accepted reluctantly with attached terms and conditions. In a world that is exuberantly enthusiastic in configuring borders flouting humanitarian legacies, the refugee is an emblem of precarity. Stateless and rightless, these minorities are harrowed by turbulent economies and slumping social justice. Designing mandates and protocols, observing international events, and organizing world summits have hardly proved effective. The nativist attitudes and policies formulated by the alleged democracies prioritizing economic equilibrium instead of international solidarity exemplify a totalitarian state politics and the nation-states craftily procure democratic consent in disposing of the refugees even before they prove as liabilities on the neoliberal economy. Subject to draconian treatment by nation-states, deprived of fundamental human rights and entitlements these destitute individuals are meted out with acute humanitarian challenges.

Economic immigration or the legally recognized immigrants who possess a valid visa and has already displayed a potential to contribute to the host economy receive the maximum share of hospitality, whereas refugees and asylum seekers, catalyze the growing anxiety and xenophobic attitudes among the nationals towards 'foreigners' as they are seen as an economic and social burden on the host economy. In the neoliberal world order, migration often becomes imperative and involuntary. It represents an aspiration to survive, re-work the material conditions of existence, and re-spin the threads of belonging in new contexts. There is a sizeable number of migrants everywhere whose journeys happen beneath the surface and in "broken" ways, migrants who exist in the new world in a way where rehabilitation remains far. The ideology of neoliberalism articulates in such a way that an individual is geo-politically ejected from the 
homeland for want of shelter and livelihood, made to move, and turned into that of a refugee. Even in many democracies, it is nativist elitism that guides policies of international cooperation, and the travel, relocating, and settlement of various people. Homi Bhabha terms their attitudes to the refugees as 'nationalistic barbarism'. I contend that it is the refugees and not the successful economic immigrants, who get branded as the dreaded stranger in the wake of indigenous nationalisms which neoliberal economies have come to embody today. Refugees and asylum seekers are those minorities who are without a home, an occupation, language, and a country--no country or nation-state is in charge of them or would protect them because they are no longer citizens; they have been either ousted from their home nation or had to flee from there; they do not belong to any nation-state, rather they are at the mercy of other potential nation-states to provide them a haven. The neoliberal nation-states often reluctantly accept refugees. The reluctance in welcoming these guests is mirrored in the impositions applied to their mobility and right to work and benefits in the receiving country. Recently, we see a new trend emerging where people seeking refuge are being compelled to prove that their reasons for leaving their home nations are genuine enough while trying to obtain shelter in some other nation.

\section{Are refugees welcomed by nation-states?}

This question entails some ruminations on the nature of hospitality received by the refugees when they seek shelter elsewhere. What is indeed striking is that reports and studies conducted worldwide on refugees are limited to the graphical representation of their growing numbers and detailing the policies implemented by receiving nation-states in handling their influx. But details on how they have been welcomed or if they feel welcomed are categorically absent from these discourses. The law of hospitality is defined by an unconditional welcome that requires national frontiers to be opened for each and every one without any reciprocity or negotiations. However, it also presupposes the sovereignty or the mastery of the receiving host nation over its territory where the refugees are harbored. Again, the refugees are not absolute strangers; the host nation has already subjected the guest to intense scrutiny and identification before the receiving and subsequent ushering. Only then the refugees are welcomed to enter the nation-state. The impossibilities implicit within the ideal of hospitality makes it structurally self-contradictory as a concept.

Nation-states owing to their liberal adherence to capitalistic tendencies camouflaged by fanatic nationalism condemns the entrance of any foreign individual who would not immediately prove an asset to them. Refugees and not economic migrants fit neatly into this category. What I am trying to state is that individuals fleeing their homeland are already relegated into a precarious position ensuing from the traumatic loss. They are accepted by nation-states obligated under the UNHCR convention of 1951. However, even after being accepted, they are meted out with atrocities of all manner. The right to hospitality is a fundamental human right and especially for those people who have been rendered stateless and rightless. The process is not at all transparent in nature. First of all, the citizens-turned-refugees have to apply for asylum or shelter in another nation-state. They have to wait at the processing centers for filing their applications, documents verification, subsequent interrogations where they have to establish that there is indeed a threat of life in the homeland. Only if the immigration officials are satisfied, they are permitted to enter the mainland of the receiving country. But here they are provided with subsidized tenements or squalid camps, they cannot find even the most menial or low-paying kind of jobs. They are often found to be begging on the streets- the underlying hostilities prevalent in the apparent hospitality of the receiving country. 
The refugees are already in a precarious situation bereft of their home, nation-state, language, and all things that were once familiar. They are amidst strangers, they are expected to feel at home and as Hannah Arendt (1994) points out, they try with all their might to forget everything they have left behind to the extent of accepting the language of the adopted nation so that they can resume the chords of belonging once again. Yet, they are treated as strangers or foreigners who have simply trespassed a national territory and are blamed for overpopulating the country or the downfall of the national economy. The receiving nation-state or the host has agreed upon a hospitable ambiance for the refugees- the guests while maintaining its authority over the latter and subjecting them to the socio-political norms of the nation-state. They are not proclaimed as citizens; they are still considered foreigners or guests who have been hosted for a temporary period; they do not enjoy all the benefits that citizenship but they have to abide by the laws more stringently than the citizens. The neoliberal nation-state remains indignant of their presence within the national perimeters.

\section{Refugee precarity during COVID-19}

The current pandemic seems to be exposing only an inherent structural contradiction deeply formative of the neoliberal totalitarian systems and economic ambitions. According to the worldsystem geographer David Harvey, the neoliberal nation-state aims to "facilitate conditions for profitable capital accumulation" $(2006,14)$ to serve the state's national (elitist) interest. Millions of refugees worldwide are exposed to violence, family separation, culture loss, and exile. The coronavirus disease further exposed these populations to a new threat, one that could prove to be more detrimental than the events forcing them to flee their homelands. Refugees are more prone to COVID-19, as they live in conditions that disproportionately increase their risk of contagion. For instance, in densely populated refugee camps, social distancing is challenging, basic sanitation and proper hygiene are almost impossible. This situation is compounded by language barriers that refugees face in host communities and their limited access to health care. For obtaining health information, testing, and treatment, which some even avoid out of fears of being deported. The social stigma associated with COVID-19 encourages illness concealment, delayed detection and treatment, increase distrust in health authorities, lowering the chances of recovery. Moreover, the COVID-19 pandemic has strained the finances of governments, non-governmental organizations, and humanitarian agencies that serve refugees. This economic crisis is further degrading the refugees' already precarious situation. The lack of legal recognition is a jarring prospect for the refugees, but even more so during a pandemic. They are hardly prioritized by health officials during COVID-19 as they are not legally recognized, economic immigrants. COVID-19 has ushered in with the most unprecedented health and socio-economic crisis, the refugees, and owing to their statelessness they are in the most precarious position than other migrants. The neoliberal nation-states have been implementing all possible measures to safeguard their national population whereas in the case of the refugees they have proved to be the weakest link in providing them with a systematic protection plan. Men, women, and children while on the move live in camps, detention, and reception centers, sometimes even huddled together in informal housing arrangements. They lack access to basic services such as clean water, sanitation, healthcare, as many do not possess a legal status--- the status that is contingent upon the receiving country's national laws. This indicates that the right to hospitality is extended only as of the temporary occupation of space without entertaining any demand for socioeconomic benefits from the guest. The neoliberal 'stay at home' policy that emerged in the wake of the pandemic to contain the virus eluded the thousands of displaced refugees who do not have a home in the first place. With most of the countries closing their borders to people seeking asylum under the pretext of contamination, the hostile underpinnings of hospitality are 
engendered and therefore Derrida states, the word hospitality, "allows itself to be parasitized by its opposite, 'hostility', the undesirable guest ... which it harbors as the self-contradiction in its own body." (2000, 1)

\section{Conclusion}

In the era of neoliberalism when global mobilities of populations and commodities are chiefly important for economic growth, the disenfranchised among the migrants is considered a liability, with the nation-states creating a hostipitable ambiance for people tramping for a shelter. Absolute hospitality is limited to the right of being a visitor. The guest might arrive at the threshold with the expectation of a temporary shelter; the guest should not be treated with any kind of hostility but the guest is also not guaranteed a permanent position within the domestic perimeters of the host. The guest's status never changes; the guest is one who is visiting the host and hence the rights of occupation of space in the household have been temporarily extended to him while the host maintains authority over the household.

Derrida claims that "...we are thus in the space of right, not of morality and politics or anything else but of a right determined in its relation to citizenship, the state, [and] the subject of the state, even if it is a world state" (Derrida 2000, 3). Fleeing from their original homelands, citizensturned-refugees embark on a journey supposedly towards a better prospective future often losing hefty amounts to smugglers with the sole desire of procuring a shelter, only to be languished in overcrowded refugee camps desperately trying to find an escape. Several refugees were stranded in the seas and land-passages during the pandemic. Jettisoned from home and receiving countries imposing restrictions on their mobility, these people are most precarious among the migrant population. Neoliberalism, as Guy Standing (2011) claims, has created this global 'precariat', “... millions around the world without an anchor of stability.” (2011:1) However, I contend that the hostilities deeply entrenched within the hospitability measures, embraced and displayed by neoliberal nation-states, to a greater or lesser extent, are responsible for the refugee precarity. The hostilities do not necessarily ensure an inhospitable ambiance and as Derrida too concedes that

“... I am not claiming that hospitality is this double bind* or this aporetic contradiction and that therefore wherever hospitality is, there is no hospitality. No, I am saying that this apparently aporetic paralysis on the threshold is...what must be overcome." (2000:14)

I attempted to highlight in this essay that the practice of hospitality or acceptation underlined by proliferating differences necessitates an interrogation of not only the COVID crisis exacerbating the vulnerabilities of the refugees but also an investigation of the nation-state ontological structures involving diverse approaches- existential, linguistic, legal, gender interacting within the wide range of models of thought for cultivating a sustainable form of hospitality in the contemporary era.

\section{References}

Arendt, Hannah. (1994). We Refugees. In Marc. Robinson (ed.), Altogether Elsewhere: Writers in Exile. Boston: Faber \& Faber. 110-119

David Harvey. (2006). Spaces of Global Capitalism: A Theory of Uneven Geographical Development. London \& New York: Verso 
Derrida, Jacques. (2000). Hostipitality. Angelaki Journal of Theoretical Humanities. 5:3 Taylor \& Francis. 3-18 DOI: 10.1080/09697250020034706

Homi Bhabha. (2019). Hannah Arendt and the New Nationalist Barbarians. The Wire. Retrieved from https://thewire.in/society/hannah-arendt-and-the-new-nationalist-barbarians

Said, Edward. (2000). Reflections on Exile and Other Essays. Cambridge, MA: Harvard University Press.

Sinha, Subir. (2012). The Long March from the Margins: Subaltern Politics, Justice, and Nature in Postcolonial India. In: Etienne Balibar, Sandro Mezzadra and Ranabir Samaddar (eds.), The Borders of Justice, pp.79-98. Philadelphia: Temple University Press

Standing, Guy. (2011). The Precariat: The New Dangerous Class. London \& New York: Bloomsbury Academic

Ms. Srinita Bhattacharjee is a doctoral candidate at the Centre for the Study of Indian Diaspora (CSID), University of Hyderabad, India. Her research pans the intricacies of Subaltern Migration in the Global South and North while probing the politics of literary and cultural representations of the disenfranchised migrants. She is a recipient of the ICSSR Doctoral Research Fellowship. She was a visiting student at the Dept. of Comparative Literature, Harvard University in 2019. Research interests: migration, transnationalism, subaltern, refugee, asylum seeker, undocumented. 